CARDOSO, AII; PIACENTI, LZ; LINO, PR; PADOVAN, IM; KRONKA, AZ. 2020. Control of Alternaria brassicicola with thermotherapy and propolis and effect on the physiological quality of kale seeds. Horticultura Brasileira 38: 363-369. Doi: http://dx.doi.org/10.1590/s0102-053620200404

\title{
Control of Alternaria brassicicola with thermotherapy and propolis and effect on the physiological quality of kale seeds
}

\author{
Antonio Ismael Inácio Cardoso ${ }^{1} \mathbb{D}$; Laura Z Piacenti ${ }^{1} \mathbb{D}$; Priscilla R Lino ${ }^{1} \mathbb{D}$; Iasmim M Padovan ${ }^{1 \mathbb{D}}$; Adriana \\ Z Kronka ${ }^{1}$ (D)
}

${ }^{1}$ Universidade Estadual Paulista (UNESP), Botucatu-SP, Brasil; antonio-ismael.cardoso@unesp.br; laurazpiacenti@gmail.com; priscilla. rugani@gmail.com; iasmim_menezes10@hotmail.com; adriana.kronka@unesp.br

\begin{abstract}
In the organic production system, the use of agrochemicals for seed treatment is prohibited. This study was carried out to evaluate the effect of heat treatment and propolis on the germination and vigor of kale seeds and the effect on the control of Alternaria brassicicola. In the treatment with wet thermotherapy, three temperatures $(50,55$ and $60^{\circ} \mathrm{C}$ ) were evaluated in separated experiments. For each temperature, five immersion times [0 (control), 15, 30, 45 and 60 minutes] were evaluated. In the dry thermotherapy treatment, seeds were submitted to constant $70^{\circ} \mathrm{C}$ temperature and five times [0 (control), 24, 48, 72 and 96 hours] were evaluated. In the treatment with propolis, six concentrations $(0.0,0.2,0.4,0.6,0.8$ and $1.0 \%)$ were studied, with subsequent washing or not washing of the seeds. Then, seeds were inoculated with $A$. brassicicola and submitted to the following treatments: wet thermotherapy at $50^{\circ} \mathrm{C}$ for 60 minutes and at $55^{\circ} \mathrm{C}$ for 15 minutes and propolis at $1.0 \%$ with and without further washing. Two control treatments were included in the experiment (inoculated untreated seeds; and not inoculated and untreated seeds), totalizing six treatments. After inoculation and treatments, the incidence of the fungus on the seeds was evaluated and the effect on the physiological quality of the seeds. Both thermotherapy treatments $\left(50^{\circ} \mathrm{C}\right.$ for 60 minutes and $55^{\circ} \mathrm{C}$ for 15 minutes) reduced the pathogen incidence significantly. Both propolis treatments at $1 \%$ (with and without subsequent washing) did not provide a satisfactory reduction on $A$. brassicicola incidence in kale seeds. Thermotherapy at $55^{\circ} \mathrm{C}$ for 15 minutes is the best option for A. brassicicola control in kale seeds, because it does not affect seed physiological quality.
\end{abstract}

Keywords: Brassica oleracea var. acephala, alternative treatments, heat treatment.

\section{RESUMO}

Controle de Alternaria brassicicola com termoterapia e própolis e efeito na qualidade fisiológica das sementes de couve

No sistema orgânico de produção é proibido o uso de agroquímicos para o tratamento de sementes. Objetivou-se com este estudo avaliar o efeito da termoterapia e da aplicação de própolis sobre a germinação e vigor de sementes de couve e no controle de Alternaria brassicicola. No tratamento com termoterapia úmida foram avaliadas três temperaturas $\left(50,55\right.$ e $\left.60^{\circ} \mathrm{C}\right)$ em experimentos separados. Para cada temperatura foram avaliados cinco tempos de imersão das sementes [0 (controle), 15, 30, 45 e 60 minutos]. $\mathrm{Na}$ termoterapia seca foram avaliados cinco tempos [0 (controle), $24,48,72$ e 96 horas] de exposição das sementes a temperatura de $70^{\circ} \mathrm{C}$. No própolis, foram estudadas seis concentrações $(0,0,0,2$, $0,4,0,6,0,8$ e 1,0\%), com posterior lavagem ou não lavagem das sementes. Depois, sementes inoculadas com $A$. brassicicola foram submetidas aos seguintes tratamentos: termoterapia úmida a $50^{\circ} \mathrm{C}$ por 60 minutos e a $55^{\circ} \mathrm{C}$ por 15 minutos, além de própolis a $1,0 \%$ com e sem lavagem posterior. Dois tratamentos controle foram incluídos neste experimento (sementes inoculadas e não tratadas; e sementes não inoculadas e não tratadas), totalizando seis tratamentos. Após a inoculação e aplicação dos tratamentos, foi avaliada a incidência do fungo nas sementes e a qualidade fisiológica das sementes. Os tratamentos térmicos $\left(60\right.$ minutos a $50^{\circ} \mathrm{C}$ e 15 minutos a $\left.55^{\circ} \mathrm{C}\right)$ reduziram significativamente a incidência da $A$. brassicicola. Os tratamentos com própolis a $1,0 \%$ (com e sem lavagem posterior) não apresentaram redução satisfatória da incidência da $A$. brassicicola nas sementes de couve. A termoterapia a $55^{\circ} \mathrm{C}$ por 15 minutos é a melhor opção para controle da $A$. brassicicola em sementes de couve, sendo a maior temperatura e tempo de exposição sem afetar a qualidade fisiológica das sementes.

Palavras-chave: Brassica oleracea var. acephala, tratamentos alternativos, tratamento térmico.

Received on May 22, 2020; accepted on August 17, 2020

$\mathrm{T}_{\mathrm{i}}^{\mathrm{k}}$ he lack of vegetable seeds produced in the organic system is a major problem for producers and certifiers in Brazil. The majority of organic vegetable cultivation is still being done with conventional seeds treated with fungicides. Among the vegetables produced in this system, brassicas stand out, due to the large volume of production, the economic return provided and the nutritional value of the crops, with leaf kale (Brassica oleracea var. acephala) being an important representative of this group. According to Vilela \& Luengo (2017), kale is the second most important leafy vegetable in Brazil. In Sao Paulo state, Trani et al. (2015) related that about 1929 ha are cultivated with kale and obtained a production of 55,941 t.

Seed quality, characterized by genetic, 
physical, sanitary and physiological aspects, has fundamental importance in the production process of any crop. The presence of microorganisms in the seeds affects their sanitary quality and, often, also affects the germination and vigor. Alternaria brassicicola is one of the pathogens that can be disseminated by brassica seeds and can cause considerable reductions in the productivity and quality of products. Mycelium of $A$. brassicicola can be found growing superficially, but also internally in seeds produced in affected crops (Kohl et al., 2010). The disease can reduce yield by $50 \%$, but the loss can be greater because only a few lesions on the leaves can make commercialization unfeasible (Peruch et al., 2006).

It is not always possible to obtain seed lots without the presence of undesirable microorganisms. For this reason, in most cases, the treatment of seeds is recommended, especially in vegetables, whose seeds are of high value and the cost of this treatment is very low compared to their cost (Cardoso et al., 2015). The use of agrochemicals is not allowed in the organic production system, neither in the production phase in the field, nor in the seeds treatment. Thus, studies about the control of pathogens transmitted by seeds in the organic system are necessary, in order to avoid the transmission of the pathogen and preserve the seeds sanitary quality, without harming the physiological quality of the lot.

Among the methods allowed in the organic production system, the thermotherapy is a physical treatment that consists of exposing the seeds to the action of heat (wet or dry) in combination with the treatment time (Braga et al., 2010; Spadaro et al., 2017). To be successful with this method, it is necessary to know the appropriate combination of temperature and exposure time, which may vary with the species, cultivar, lot, initial vigor, among other factors (Lanna et al., 2013; Divsalar et al., 2014). The treatment principle is based on the difference in lethal thermal points, that is, the temperature must be higher than the lethal temperature for the pathogen, without harming the seeds (Grondeau \&
Samson, 1994).

Although the alternative control of pathogens with heat treatment has proven to be efficient, there are few studies on this technology and, mainly, its effect on the physiological potential of the seeds (Braga et al., 2010; Lanna et al., 2013), as the heat treatment can reduce the germination and the vigor of the seeds.

In addition to heat treatment, there are other alternative seed treatments, such as the application of propolis extract, which is a product with antimicrobial properties. This product has presented good results in the control of seed pathogens (Souza et al., 2017). According to Silva et al. (2006), the product consists of a series of resinous substances, which bees use to protect the hive against the proliferation of microorganisms, including fungi and bacteria.

In view of the above, and considering the need for the eventual replacement of chemicals by alternative seed treatments in the organic production system, the objective was to evaluate the effect of heat treatment and use of propolis on the control of Alternaria brassicicola, and their effect on germination and vigor of kale seeds.

\section{MATERIAL AND METHODS}

The experiments were conducted at the Vegetable Seeds Laboratory of the Horticulture Department of the School of Agriculture (FCA) of Sao Paulo State University (UNESP), Botucatu-SP.

The kale seeds (cultivar Manteiga without fungicide treatment) were purchased from the company Feltrin. In the first step, an old, low vigor seed lot was used, because, according to Lanna et al. (2013), it is more sensitive to heat treatment and, therefore, better at detecting differences among treatments. For propolis treatment and the second step, a new seed lot was used to study the effect of the treatments on the control of the A. brassicicola in kale seeds. The isolate of $A$. brassicicola was provided by Sakata Seed Sudamerica and was initially obtained from a broccoli production field in the municipality of Senador Amaral-MG, later identified and maintained by the company's phytopathology sector.

Step 1) Effect of thermotherapy (wet and dry) and propolis on seed germination and vigor

Five experiments were carried out on the treatment of kale seeds by different methods: wet thermotherapy (testing three temperatures), dry thermotherapy and propolis.

In the treatment with wet thermotherapy, three temperatures $\left(50,55\right.$ and $\left.60^{\circ} \mathrm{C}\right)$ were evaluated in separate experiments. For each temperature, five seed immersion times (treatments) [0 (control), 15, 30, 45 and 60 minutes] were evaluated. The seeds were immersed in water, at constant temperature, in the time provided for each treatment. After each treatment, the seeds were cooled under distilled water and dried in a forced air seed dryer at $35^{\circ} \mathrm{C}$ for $24 \mathrm{~h}$. After drying, the seeds were placed in a chamber $(40 \%$ $\mathrm{RH}$ and $20^{\circ} \mathrm{C}$ ), until the water content stabilization at $8 \%$.

In dry thermotherapy treatment, seeds were submitted to a constant $70^{\circ} \mathrm{C}$ temperature in a forced air circulation oven, and five exposure times (treatments) [0 (control), 24, 48, 72 and 96 hours] were evaluated.

In the treatment with propolis (commercial product Apis Flora), twelve treatments were studied, resulting from the factorial $6 \times 2$, with six propolis concentrations $(0.0,0.2,0.4,0.6,0.8$ and $1.0 \%$ ), with and without washing the seeds after the treatment. The seeds were stirred for 30 minutes in a becker with the propolis solution and a part of these seeds was later washed in distilled water to remove the product and the other part was not washed. After this procedure, the seeds were dried in the forced air seed dryer at $35^{\circ} \mathrm{C}$ for $24 \mathrm{~h}$. After drying, the seeds were placed in a chamber $\left(40 \% \mathrm{RH}\right.$ and $\left.20^{\circ} \mathrm{C}\right)$, until the water content stabilization at $8 \%$.

In each experiment, germination tests were set up, placing 50 seeds per plot, with four replicates, evenly distributed over two sheets of germinating paper moistened to 2.5 times their dry weight 
with distilled water, in transparent plastic boxes (gerbox). The experiment was carried out in a Biochemical Oxygen Demand (BOD) germinator, at a temperature of $25 \pm 1^{\circ} \mathrm{C}$. The total number of germinated seeds at ten days after sowing (DAS) was considered as the total germination. Germinated seeds were considered when they had primary root and aerial part. The first count of the germination test was carried out at five DAS, and considered as a vigor test (Brasil, 2009). The germination speed index (GSI) was also obtained, with the values of germinated seeds day by day, according to Maguire (1962).

Data were submitted to analysis of variance in an entirely random design and, when significant, regression analysis was performed for seed treatment times in water and dry heat and for propolis concentrations. The $\mathrm{F}$ test was used to compare the washing, or not, of the seeds in propolis experiment. For the analysis, the Sisvar program was used.

Step 2) Control of Alternaria brassicicola in kale seeds

From the first step, four treatments were select: wet thermotherapy, at a temperature of $50^{\circ} \mathrm{C}$ with immersion for 60 minutes; wet thermotherapy, at a temperature of $55^{\circ} \mathrm{C}$ with immersion for 15 minutes; propolis treatments, at a concentration of $1.0 \%$, with and without washing after treatment. These treatments did not harm (or harmless) seeds physiological quality (germination and vigor). Two control treatments were included in the experiment (inoculated untreated seeds; and not inoculated and untreated seeds), totalizing six treatments.

The A. brassicicola isolate was grown in Petri dishes containing PDA culture medium and, after seven days of incubation at $25^{\circ} \mathrm{C}$ and $12 \mathrm{~h}$ photoperiod, disks of $0.5 \mathrm{~cm}$ of fungal colony were removed and transferred to Petri dishes containing PDA plus mannitol $(33.10 \mathrm{~g}$ $\mathrm{L}^{-1}$ ). After the fungus had colonized the entire plate, kale seeds (without chemical treatment), previously disinfected in $2 \%$ sodium hypochlorite for one minute and dried on sheets of sterile filter paper, were deposited in a single layer, remaining in contact with the colonies for 24 hours. After inoculation, the seeds were again disinfested with $2 \%$ sodium hypochlorite and dried.

After being inoculated and treated as described above, seeds were evaluated by the "blotter test", placing in plastic Petri dishes three filter paper sheets, which had been previously moistened with distilled water and distributing 25 equidistant seeds on this substrate. Four repetitions of 25 seeds per treatment were performed. The plates containing the seeds were incubated in BOD at $20 \pm 2^{\circ} \mathrm{C}$ with a $12 \mathrm{~h}$ photoperiod for seven days. After this period, the seeds were examined individually, under a stereomicroscope, in order to evaluate the fungus incidence. The results were expressed as percentage of seeds infected with $A$. brassicicola.

In addition to the blotter test, seeds germination and vigor (first count of germination and GSI) were also evaluated according to Brasil (2009), as previously described.

Analysis of variance was performed for each variable (fungus incidence, germination, first count and GSI) in an entirely random design and the means were compared using the Tukey test $(5 \%)$. For the statistical analysis, the Sisvar program was used.

\section{RESULTS AND DISCUSSION}

In the dry thermotherapy at $70^{\circ} \mathrm{C}$, regardless of the seed treatment time, no germinated seeds were observed, showing that this temperature was lethal to kale seeds from the tested lot. Only the control showed values of germination $(52.5 \%)$, first count of germination (12.5\%) and GSI (4.17) different from zero.

These results differ from those reported by Lanna (2018) who did not observe reduction in the germination of zucchini seeds treated with dry thermotherapy at $70^{\circ} \mathrm{C}$ for up to $96 \mathrm{~h}$. Gama et al. (2014) reported that fennel seeds did not lose quality when treated with dry thermotherapy at $70^{\circ} \mathrm{C}$ for up to 15 days. However, the germination of cucumber seeds gradually decreased the longer the treatment time with dry thermotherapy at $70^{\circ} \mathrm{C}$ (Shi et al., 2016). Kubota et al. (2012) also reported reduction in the germination of seeds of different cucurbits with dry thermotherapy, the greater the reduction the greater the temperature and the treatment time. However, none of these mentioned studies presented total reduction in germination as occurred with kale seeds. Another fact that can contribute to our results is that an old seed lot with low physiological quality was used and these seeds showed greater sensitivity to heat treatment. Therefore, this method should not be recommended for the treatment of kale seeds, at least at the temperature tested, which is the same tested in most researches with other species of seeds.

The germination and vigor tests showed that the wet heat treatment at $60^{\circ} \mathrm{C}$ is lethal for kale seeds with more than 15 minutes treatment (Table 1). However, even with 15 minutes, germination has already been drastically reduced, showing that treatment with this temperature is not feasible. Grondeau \& Samson (1994) described that wet thermotherapy should be applied at a temperature from 45 to $60^{\circ} \mathrm{C}$ for a maximum exposure period of 60 minutes, regardless of the species. Although the temperature is within the range recommended by these authors, the use of $60^{\circ} \mathrm{C}$ is not recommended for the treatment of kale seeds. Spadaro et al. (2017) recommend that the treatment of organic seeds by this method should be carried out with temperatures ranging from 50 to $55^{\circ} \mathrm{C}$, not recommending $60^{\circ} \mathrm{C}$. Nega et al. (2003), Braga et al. (2010), Soriano et al. (2011) and Lanna (2018) also related this same conclusion for different species. However, Cunha et al. (2017) reported that the immersion of zucchini seeds at $60^{\circ} \mathrm{C}$ for up to 18 minutes did not affect the physiological quality of the seeds.

As the time of exposure of the seeds to the wet heat treatment at $55^{\circ} \mathrm{C}$ increased, a reduction in the rate of germination and vigor was observed (Figure 1), the reduction being more pronounced after 15 minutes treatment. Regarding the observed values (Table 1), it can be seen that after 15 minutes germination was even numerically superior to the control without treatment 
for the first count of germination and GSI.

On the other hand, for all evaluated characteristics (germination, first count and GSI) no significant difference was observed by the $F$ test $(5 \%)$ and regression analysis for the immersion times tested (15 to 60 minutes) when the seeds were treated in water at $50^{\circ} \mathrm{C}$ (Table 1). For the first count of germination, an average of $14.1 \%$ was observed at five days after sowing, total germination showed an average of $51.5 \%$ and for the GSI, an average of 4.2. Thus, wet thermotherapy at a temperature of $50^{\circ} \mathrm{C}$ did not affect the physiological quality of the seeds, even for this low quality seed lot, and this treatment can be recommended for kale seeds.
The results observed in the literature vary according to temperature, treatment time and the species studied. Braga et al. (2010) demonstrated that tomato seeds treated at $52,53,54$ and $55^{\circ} \mathrm{C}$ for 30 minutes presented lower germination than those not treated with thermotherapy. Corn seeds showed a loss of vigor when treated at $70^{\circ} \mathrm{C}$ for 3 minutes, but not when the treatment was at $50^{\circ} \mathrm{C}$ and $60^{\circ} \mathrm{C}$ (Vieira et al., 2019).

In Brassicas, Soriano (2016) reported decreased germination the longer the seed exposure time to treatment at $55^{\circ} \mathrm{C}$. Lanna et al. (2013) found that thermotherapy at a temperature of $58^{\circ} \mathrm{C}$ was lethal to cabbage seeds, and at $55^{\circ} \mathrm{C}$ there was loss of germination and vigor the longer the time of exposure to heat treatment. Nega et al. (2003) and

Table 1. Germination, first count and germination speed index (GSI) of kale seeds treated by wet thermotherapy at $60^{\circ} \mathrm{C}, 55^{\circ} \mathrm{C}$ and $50^{\circ} \mathrm{C}$ for different times. Botucatu, UNESP, 2019.

\begin{tabular}{|c|c|c|c|}
\hline \multirow{2}{*}{ Treatment } & First count $(\%)$ & Germination (\%) & GSI \\
\hline & \multicolumn{3}{|c|}{$60^{\circ} \mathrm{C}$} \\
\hline Control & 12.5 & 52.5 & 4.17 \\
\hline $60^{\circ} \mathrm{C} / 15$ minutes & 0.0 & 12.0 & 0.69 \\
\hline $60^{\circ} \mathrm{C} / 30$ minutes & 0.0 & 0.0 & 0.00 \\
\hline $60^{\circ} \mathrm{C} / 45$ minutes & 0.0 & 0.0 & 0.00 \\
\hline $60^{\circ} \mathrm{C} / 60$ minutes & 0.0 & 0.0 & 0.00 \\
\hline $\mathrm{CV}(\%)$ & - & - & - \\
\hline \multirow[t]{2}{*}{$\mathrm{F}$} & - & - & - \\
\hline & \multicolumn{3}{|c|}{$55^{\circ} \mathrm{C}$} \\
\hline Control & 12.5 & 52.5 & 4.17 \\
\hline $55^{\circ} \mathrm{C} / 15$ minutes & 17.0 & 49.5 & 4.65 \\
\hline $55^{\circ} \mathrm{C} / 30$ minutes & 0.0 & 20.5 & 1.32 \\
\hline $55^{\circ} \mathrm{C} / 45$ minutes & 0.0 & 15.5 & 0.95 \\
\hline $55^{\circ} \mathrm{C} / 60$ minutes & 0.0 & 2.0 & 0.14 \\
\hline CV $(\%)$ & 46.5 & 18.7 & 25.1 \\
\hline \multirow[t]{2}{*}{$\mathrm{F}$} & $35.6^{* *}$ & $71.2 * *$ & $51.7^{* *}$ \\
\hline & \multicolumn{3}{|c|}{$50^{\circ} \mathrm{C}$} \\
\hline Control & 15.0 & 54.2 & 4.32 \\
\hline $50^{\circ} \mathrm{C} / 15$ minutes & 14.5 & 49.2 & 3.81 \\
\hline $50^{\circ} \mathrm{C} / 30$ minutes & 13.5 & 52.0 & 4.06 \\
\hline $50^{\circ} \mathrm{C} / 45$ minutes & 13.0 & 51.0 & 4.06 \\
\hline $50^{\circ} \mathrm{C} / 60$ minutes & 14.5 & 51.0 & 4.08 \\
\hline CV (\%) & 14.9 & 7.9 & 6.5 \\
\hline $\mathrm{F}$ & $0.6^{\mathrm{ns}}$ & $0.5^{\mathrm{ns}}$ & $0.2^{\mathrm{ns}}$ \\
\hline
\end{tabular}

$\mathrm{ns}=$ not significant at $5 \%$ probability $; *=$ significant at $1 \%$ probability $\mathrm{CV}=$ coefficient of variation.
Soriano et al. (2011) do not recommend seed treatments at $55^{\circ} \mathrm{C}$ for more than 40 minutes for Brassicas seeds.

According to Coutinho et al. (2007), the treatment with hot water can cause denaturation of the external tissues and/ or rupture of the seed coat, deteriorating the seeds quickly in comparison to the seeds not treated by thermotherapy. The higher the temperature and the treatment time, the greater the probability of causing damage to the seeds. Based on the observed results, dry thermotherapy at $70^{\circ} \mathrm{C}$ is not recommended. The treatment at $50^{\circ} \mathrm{C}$ did not affect the seed's germination and vigor, being chosen the longest time (60 minutes) to continue the research, because the longer the time, the greater the probability of controlling fungi in the seeds. On the other hand, at $55^{\circ} \mathrm{C}$ a gradual reduction in seed quality was observed the longer the treatment time; therefore, the shorter time (15 minutes) was chosen because having less germination reduction compared to the other tested times.

In propolis treatments, no significant difference was observed for germination, first count and GSI, with an average of $81.5 \%, 26.9 \%$ and 7.3 , respectively.

Thus, the highest concentration used, $1.0 \%$, and the factors with and without washing did not negatively affect the physiological quality of kale seeds, as observed by Souza et al. (2017) and Fraga et al. (2016) with cucumber and carrot seeds.

A. brassicicola incidence in uninoculated, untreated seeds was $0.8 \%$, showing that the seed lot used had a low incidence of this fungus, whereas in the inoculated, untreated control the incidence was $92.0 \%$, showing that the seed inoculation was efficient (Table 2).

Treatment with $1.0 \%$ propolis without washing reduced the incidence of the pathogen by almost half (43.2\%) compared to the inoculated control (92.0\%). There was no $A$. brassicicola control when seeds were washed after being treated with $1.0 \%$ propolis. The fungus could be observed in $88 \%$ of seeds from that treatment, not differing from the inoculated, untreated control (Table 2). Therefore, the washing of seeds after treatment with propolis, caused lost of fungus control in kale 
seeds.

Souza et al. (2017) observed that the higher the concentration of propolis $(0$ to $20 \%$ ), the lower the mycelial growth in vitro of Penicillium sp., and at the concentration of $20 \%$ there was no development of the fungus. The probable reason is the concentration of flavonoids contained in propolis, which have an antimicrobial effect. On the other hand, Carvalho et al. (2019) reported that propolis extract (up to $25 \%$ ) was not

Table 2. Incidence of Alternaria brassicicola, germination, first count and germination speed index (GSI) of kale seeds after different treatments. Botucatu, UNESP, 2019.

\begin{tabular}{lcccc}
\hline Treatment & $\begin{array}{c}\text { Incidence } \boldsymbol{A} \text {. } \\
\text { brassicicola } \mathbf{( \% )}\end{array}$ & $\begin{array}{c}\text { Germination } \\
\mathbf{( \% )}\end{array}$ & $\begin{array}{c}\text { First count } \\
\mathbf{( \% )}\end{array}$ & GSI \\
\hline Control without inoculation & $0.8 \mathrm{a}$ & $89.2 \mathrm{a}$ & $44.4 \mathrm{a}$ & $8.25 \mathrm{a}$ \\
Inoculated control & $92.0 \mathrm{c}$ & $53.2 \mathrm{~b}$ & $16.8 \mathrm{~b}$ & $6.61 \mathrm{c}$ \\
Thermoterapy at $50^{\circ} \mathrm{C} / 60 \mathrm{~min}$ & $0.8 \mathrm{a}$ & $74.4 \mathrm{a}$ & $17.2 \mathrm{~b}$ & $6.09 \mathrm{bc}$ \\
Thermoterapy at $55^{\circ} \mathrm{C} / 15 \mathrm{~min}$ & $0.8 \mathrm{a}$ & $85.6 \mathrm{a}$ & $46.8 \mathrm{a}$ & $8.30 \mathrm{a}$ \\
Propolis at $1 \%$, without wash & $43.2 \mathrm{~b}$ & $84.4 \mathrm{a}$ & $42.0 \mathrm{a}$ & $8.28 \mathrm{a}$ \\
Propolis at $1 \%$, with wash & $88.0 \mathrm{c}$ & $80.2 \mathrm{a}$ & $37.0 \mathrm{a}$ & $7.60 \mathrm{ab}$ \\
\hline $\mathrm{CV}(\%)$ & 23.5 & 7.2 & 16.0 & 7.6 \\
\hline
\end{tabular}

Averages followed by the same letter, in columns, do not differ from each another, by the Tukey test at $5 \%$ probability. CV $=$ coefficient of variation.

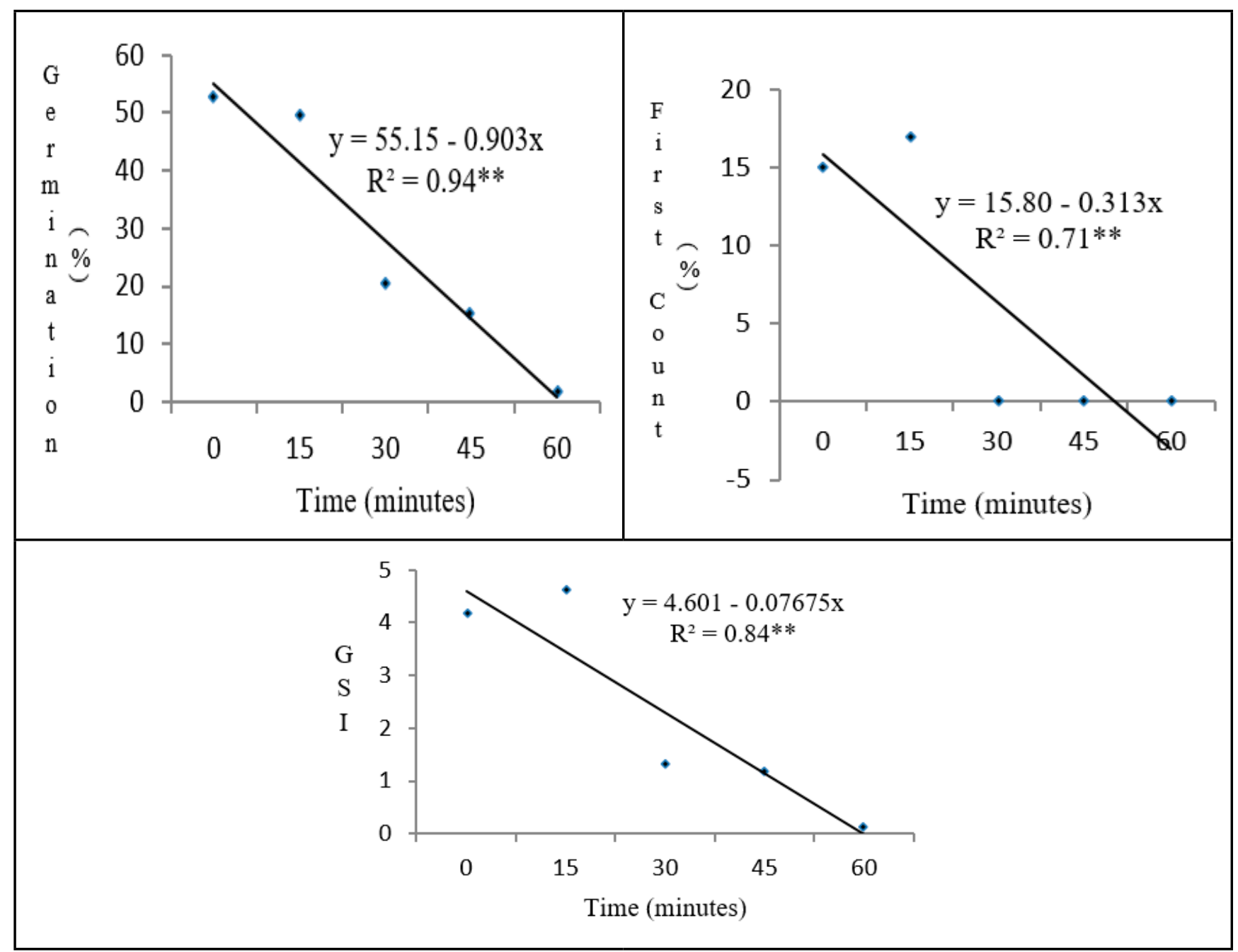

Figure 1. Germination, first count and germination speed index (GSI) of kale seeds according to exposition time to wet thermotherapy at $55^{\circ} \mathrm{C}$. Botucatu, UNESP, 2019. 
effective in controlling Aspergillus sp. in onion seeds. In brassica seeds, mycelium of $A$. brassicicola can be found growing superficially, but also internally (Kohl et al., 2010); propolis has a protective effect, acting on seed surface but, with washing after seed treatment, there was no effect on fungi control.

Therefore, there are divergences among the different researches cited. However, each research has its particularities, that is, different pathogens were evaluated, different concentrations of propolis extract, treatment exposure times, in addition to the fact that, many times, the evaluation is done only in vitro, that is, with the fungus in petri dish, not in seeds. In addition, Fernandes et al. (2006) also state that the effectiveness of propolis may vary according to the place of production. The chemical composition of propolis is extremely complex, because of the great variability of the Brazilian flora and the seasonal conditions of the area. Silva et al. (2006) analyzed propolis for physico-chemical composition and antimicrobial activity according to the sample collection period; he detected variable flavonoid content (bioactive compound) in samples collected in the winter, which varied between $0.27 \%$ and $0.38 \%$, while in the summer it varied from $0.19 \%$ to $0.52 \%$.

Both thermotherapy treatments, $50^{\circ} \mathrm{C}$ for 60 minutes and $55^{\circ} \mathrm{C}$ for 15 minutes, reduced the incidence of the fungus to $0.8 \%$, not differing significantly from the uninoculated control (Table 2), showing the efficiency of these treatments almost eradicating $A$. brassicicola in the seeds. Soriano (2016) also reported control of Xanthomonas campestris pv. campestris in kale seeds with thermotherapy at $50^{\circ} \mathrm{C}$ for 20 and 40 minutes.

Treatment by wet thermotherapy has been an efficient method in different vegetable species. Silva et al. (2018) reported 100\% control of Fusarium oxysporum f. sp. cepae on onion seeds with thermotherapy treatment at $60^{\circ} \mathrm{C}$. Nega et al. (2003) observed reduction over $85 \%$ of different species of Alternaria in carrot seeds with hot water treatments at $50^{\circ} \mathrm{C}$ for 30 minutes and $53^{\circ} \mathrm{C}$ for 10 minutes. These results show the efficiency of thermotherapy in the control of different Alternaria species in vegetable seeds, confirming the result obtained in the present research.

Schaad \& Alvares (1993) state that cabbage, broccoli and Brussels sprouts seeds should be treated at $50^{\circ} \mathrm{C}$ for 25 minutes, and cauliflower, kohlrabi, kale, turnip and turnip greens seeds should be treated for 15 minutes. In this research, the treatment at $50^{\circ} \mathrm{C}$ for 60 minutes was effective in controlling $A$. brassicicola in kale seeds.

According to Kohl et al. (2010), A. brassicicola is a pathogen of great importance in the organic production of brassica, especially when transmitted by seeds. Heat treatment can be an alternative to this fungus control in brassica seeds in the organic system. However, it will only be efficient as part of the management strategy, which begins in the field of seed production, with preventive measures against infection by this fungus in the seeds.

An accentuated reduction in seeds germination and vigor was observed comparing inoculated untreated seeds to the not inoculated, untreated control (Table 2), showing that infection by this pathogen harms seeds physiological quality. According to Kohl et al. (2010), in organic seed production of Brassica vegetables, infections by $A$. brassicicola can cause severe losses in seed quality (germination and vigor). Nega et al. (2003) observed that the germination and the first count of germination in some brassica seeds were lower when inoculated with the bacterium $X$. campestris pv. campestris, in relation to the control without inoculation. Infection of seeds by fungi and bacteria, in addition to promoting their dissemination, also harms their physiological quality.

Thermotherapy or propolis treatments did not affect the germination of the seeds compared to the control (Table 2). However, the treatment with thermotherapy at $50^{\circ} \mathrm{C}$ for 60 minutes resulted in lower values in the first count of germination and in the GSI, that is, less vigor, similar to inoculated, untreated treatment. Kohl et al. (2010) reported that the heat treatment at $50^{\circ} \mathrm{C}$ did not affect the germination of cabbage seeds naturally infected by $A$. brassicicola.

Considering that the minimum standard for kale seed germination for commercialization is $80 \%$ (Brasil, 2013), only seeds from inoculated, untreated treatment or submitted to thermotherapy treatment at $50^{\circ} \mathrm{C}$ for 60 minutes (Table 2) could not be commercialized, besides the inoculated and not treated seeds.

The reduction in germination and vigor in the inoculated and untreated seeds occurred because the fungus colonized the seed. For the thermotherapy treatment, the longer treatment time (60 minutes) harmed germination. According to Coutinho et al. (2007), the treatment with hot water can cause denaturation of the external tissues and/or rupture of the seed coat, impairing the vigor of the seeds, as observed in the heat treatment at $50^{\circ} \mathrm{C}$ for 60 minutes, due to the longer exposure time of the seeds to hot water. Furthermore, according to Nakagawa (1999), the successive treatments (disinfestation, inoculation and thermotherapy) can compromise the germination of the lots, an effect similar to the study of accelerated aging in seeds, which causes stress through the exposure of the seeds immersed in water, and reduces significantly seed germination and vigor. So, it can explain the results observed in thermotherapy at $50^{\circ} \mathrm{C}$ for 60 minutes different from the first step.

Treatment with $1.0 \%$ propolis did not affect the germination and vigor of the kale seeds, similar to that observed by Souza at al. (2017) where the application of propolis extract solutions (up to $20 \%$ concentration) did not affect the physiological quality of cauliflower seeds. Fraga et al. (2016) did not observe reduction in the physiological quality of carrot seeds when submitted to solutions of propolis extract in concentrations of 2, 4, 8 and $16 \mathrm{~mL} \mathrm{~L}^{-1}$ distilled water.

Therefore, thermotherapy at $55^{\circ} \mathrm{C}$ for 15 minutes is the best option for controlling $A$. brassicicola in kale seeds, without significantly affect the physiological quality of the seeds. 


\section{ACKNOWLEDGEMENTS}

The authors acknowledge the CNPq for the scholarships granted and to Dr. Katia Brunelli (Sakata Seed Sudamerica) for the A. brassicicola isolate.

\section{REFERENCES}

BRAGA, MP; OLINDA, RA; HOMMA, SR; DIAS, CTS. 2010. Relationships between thermal treatment, germination, vigor and health of tomato seeds. Revista Brasileira de Sementes 32: 101-110.

BRASIL. 2009. Ministério da Agricultura, Pecuária e Abastecimento. Regras para análise de sementes. Brasília: Mapa/ACS. p.395-399.

BRASIL. 2013. Ministério da Agricultura, Pecuária e Abastecimento. Instrução Normativa $\mathrm{n}^{\circ} 45$, de 17 de setembro de 2013. Diário Oficial [da] República Federativa do Brasil, Brasília. p.21.

CARDOSO, AII; LANNA, NBL; SILVA, PNL; NAKADA-FREITAS, PG; SANTOS, PL; PIEROZZI, CG; KRONKA, AZ. 2015. Germination, vigor and pathogen incidence in broccoli seed treated with Carboxin + Thiram. African Journal of Agricultural Research 10: $1-5$.

CARVALHO, BL; SOUZA, EP; ANJOS, LVS; NAKADA-FREITAS, PG; CARDOSO, AII; AMADOR, TS; SANTOS, TP; MAGALHÃES, TH. 2019. Treatment of onion seeds with propolis extract and Plectranthus amboinicus in the control of Aspergillus sp. Brazilian Journal of Biosystems Engineering 13: 12-18.

COUTINHO, WM; SILVA-MANN, R; VIEIRA, MGGC; MACHADO, CF; MACHADO, JC. 2007. Health and physiological quality of maize seeds submitted to thermotherapy and physiological preconditioning. Fitopatologia Brasileira 32: 458-464.

CUNHA, RP; CARVALHO, IL; OLSEN, D; VIEIRA, JF; SOARES, VN; TUNES, LM. 2017. Thermoterapy in pumpkin seeds to control seed born pathogens fungi. Tecnologia \& Ciência Agropecuária 11: 53-57.

DIVSALAR, M; SHAKERI, M; KHANDAN, A. 2014. Study on thermotherapy treatment effects on seed germination and vigor of tomato cultivars. International Journal of Plant \& Soil Science 3: 799-809.

FERNANDES, A; LOPES, MMR; COLOMBARI, V; MONTEIRO, ACM; VIEIRA, EP. 2006. Atividade antimicrobiana de própolis de Apis mellifera obtidas em três regiões do Brasil. Ciência Rural 36: 294-297.

FRAGA, GP; SILVA, MAS; DUARTE, TS; PEZZI, LD. 2016. Efeito de doses de própolis sobre germinação de sementes de cenoura. In: CONGRESSO BRASILEIRO DE OLERICULTURA, 54. Anais... Recife: ABH, p.667.

GAMA, JSN; ARAUJO NETO, AC; BRUNO, RLA; PEREIRA JUNIOR, LR; MEDEIROS, JGF. 2014. Thermotherapy in treating fennel seeds (Foeniculum vulgare Mill.): effects on health and physiological quality. Revista Ciência Agronômica 45: 842-849.

GRONDEAU, C; SAMSON, R. 1994. A review of thermotherapy to free plant materials from pathogens, especially seeds from bacteria. Critical Reviews in Plant Sciences 13: 57-75.

KOHL, J; TONGEREN, CAM; GRENENBOOM, BH; HOOF, RA; DRIESSEN, R.; HEIJDEN, L. 2010. Epidemiology of dark leaf spot caused by Alternaria brassicicola and A. brassicae in organic seed production of cauliflower. Plant Pathology 59: 358-367.

KUBOTA, M; HAGIWARA, N; SHIRAKAWA, T. 2012. Disinfection of seeds of cucurbit crops infested with Acidovorax citrulli with dry heat treatment. Journal of Phytopathology 160: 364-368.

LANNA, NBL. 2018. Composto orgânico e torta de mamona na produção e qualidade de frutos e sementes de abobrinha-de-moita. Botucatu: UNESP.109p. (Ph.D. thesis).

LANNA, NBL; SILVA, PNL; PASSINI, LA; SORIANO, F; CARDOSO, AII. 2013. Effect of thermoterapy in germination and vigor of broccoli organic seeds. Cadernos de Agroecologia 8: 1-5.

MAGUIRE, JD. 1962. Speed of germination aid in selection and evaluation for seedling emergence and vigour. Crop Science 2: 176-177.

NAKAGAWA, J. 1999. Testes de vigor baseados no desempenho das plântulas. In: KRZYZANOWSKI, FC; VIEIRA, RD; FRANÇA NETO, JB (eds). Vigor de sementes: conceitos e testes. Londrina: ABRATES, p.21-23.

NEGA, E; ULRICH, R; WERNER, S; JAHN, M. 2003. Hot water treatment of vegetable seed an alternative seed treatment method to control seed borne pathogens in organic farming. Journal of Plant Diseases and Protection 110: 220-234.

PERUCH, LAM; MICHEREFF, SJ; ARAÚJO, IB. 2006. Survey of the intensity of Alternaria black spot and black rot on brassica species under organic farming systems in Pernambuco and Santa Catarina states, Brazil. Horticultura Brasileira 24: 464-469.
SCHAAD, NW; ALVAREZ, A. 1993. Xanthomonas campestris pv. campestris cause of black rot of crucifers. In: SWINGS, JG; CIVEROLO, EL (eds). Xanthomonas. Londres: Chapman \& Hall, p.51-55.

SHI, Y; MENG, S; XIE, X; CHAI, A; LI, B. 2016. Dry heat treatments reduces the occurrence of Cladosporium cucumerinum, Ascochyta citrullina, and Colletotrichum orbiculare on the surface and interior of cucumber seeds. Horticultural Plant Journal 2: 35-40.

SILVA, PP, FREITAS, RA.; NASCIMENTO, WM. 2018. Recovery of onion seeds treated by thermotherapy and submitted to osmoconditioning. Acta Horticulturae 1204: 133-138.

SILVA, RA; RODRIGUES, AE; RIBEIRO, MCM; CUSTÓDIO, AR; ANDRADE, NED; PEREIRA, WE. 2006. Physicochemical characteristics and antimicrobial activity of the extracts propolis of the Paraiba, Brazil. Ciência Rural 36: 1842-1848.

SORIANO, F. 2016. Avaliação da termoterapia no controle de Xanthomonas campestris pv. campestris em sementes orgânicas de couve 'Manteiga'. Botucatu: UNESP. 78p. (M.Sc. dissertation).

SORIANO, F; CLAUDIO, MTR; CARDOSO, AII. 2011. Termoterapia em sementes orgânicas de brócolis. In: Congresso Brasileiro de Olericultura, 51. Resumos... Viçosa: ABH (CD-ROM).

SOUZA, EP; PERINO, FHB; MOSCATO, BS; FREITAS, PGN; BLUMER, S; CARDOSO, AII; BONINI, CSB; BONINI NETO, A. 2017. Extract of propolis in control of Penicillium sp. and in the quality of cauliflower seeds. Brazilian Journal of Biosystems Engineering 11: 135-141.

SPADARO, D; HERFORTH-RAHMÉ, J; WOLF, J. 2017. Organic seed treatments of vegetables to prevent seedborne diseases. Acta Horticulturae 1164: 23-31.

TRANI, PE; TIVELLI, SW; BLAT, SF; PRELAPANTANO, A; TEIXEIRA, EP; ARAÚJO, HS; FELTRAN, JC; PASSOS, FA; FIGUEIREDO, GJB; NOVO, MCSS. 2015. Couve de folha: do plantio à pós-colheita. Campinas: IAC, 36p. (Technical Bulletin, 214).

VIEIRA, H; MARTINS, JVS; BARRETO, GG; GOMES, RSS; SILVA, EC; NASCIMENTO, LC. 2019. Sanitary and physiological quality of 'purple' corn (Zea mays L.) seeds submitted to thermotherapy. Arquivo Instituto Biológico 86: 1-7.

VILELA, NJ; LUENGO, RFA. 2017. Produção de hortaliças folhosas no Brasil. Campo \& Negócios. <Available at http://www. revistacampoenegocios.com.br/producaode-hortalicas-folhosas-no-brasil>. Accessed July 20, 2020. 